\title{
Associaton between violence and drug consumption with suicide in lesbians, gays, bisexuals, transvestites, and transsexuals: cross-sectional study
}

Grayce Alencar Albuquerque, ${ }^{1}$ Francisco Winter dos Santos Figueiredo, ${ }^{2}$ Laércio da Silva Paiva, ${ }^{2}$ Márcio Flávio Moura de Araújo, ${ }^{3}$ Erika da Silva Maciel, ${ }^{4}$ Fernando Adami ${ }^{2}$

Universidade Regional e Cariri, Ceará, Brasil.

2 Faculdade de Medicina do ABC, Santo André, Brasil.

3 Universidade da Intergração Internacional da Lusofonia Afro-Brasileira, Redenção, Brasil.

${ }^{4}$ Centro Universitario Lutherano de Palmas, Palmas, Brasil.

\section{Correspondence:}

Márcio Flávio Moura de Araújo Instituto de Ciéncias da Saúde, Universidade da Integração Internacional da Lusofonia Afro-Brasileira. Rodovia CE 060 - Km 51, Zip Code: 62785-00, Acarape, CE, Brasil. Phone: + 55 (85) 33321414 Email: marciofma@yahoo.com.br

Received: 30 October 2017 Accepted: 4 Mayo 2018

\section{Citation:}

Albuquerque, G. A., dos Santos Figueiredo, F. W., da Silva Paiva, L., Moura de Araúio, M. F., da Silva Maciel, E., Adami, F. Associaton between violence and drug consumption with suicide in lesbians, gays, bisexuals, transvestites, and transsexuals: cross-sectional study. Salud Mental, $41(3), 131-138$. doi: $10.17711 /$ SM.0185-3325.2018.015

\section{cc) (i) (S)}

\begin{abstract}
Introduction. Lesbian, gay, bisexual, transvestite, and transgender (LGBT) people are affected by prejudice and psychological, physical, and/or sexual violence due to their sexual orientation. Objective. To analyze the association between violence, drug use, and suicide in LGBT people. Method. We interviewed 316 LGBT people from two cities of the Brazilian Northeast by means of a structured instrument. This included questions about sociodemographic data, sexual orientation, type of violence, type and quantity of drugs consumed, and suicide. Results. There was a positive association between physical violence and anabolic consumption ( $p=$ $.001)$ and tranquilizers $(p=.012)$. In relation to psychological and verbal violence, there was a positive association with the use of tranquilizers $(p=.021)$ and negative with the use of amphetamines $(p=.027)$. Suicide attempts were associated with having experienced physical $(p=.03)$ and sexual $(p=.037)$ violence. Drug use, especially ecstasy, cocaine, marijuana, and tranquilizers, was also associated with suicide attempts ( $p$ $=.002, p=.031, p<.001, p<.001$, respectively). The participants who had already attempted suicide were more vulnerable to experience violence and consume drugs within 30 days prior to the interview $(p<.001)$. Discussion and conclusion. Psychological/verbal violence showed to be associated with the use of amphetamines, while physical violence was associated with a higher consumption of tranquilizers and anabolic steroids. Suicide attempts were more common among participants who had suffered physical violence and who were users of substances such as ecstasy, cocaine, marijuana, and tranquilizers.
\end{abstract}

Keywords: Homosexuality, bisexuality, violence, psychotropic medications.

\section{RESUMEN}

Introducción. Las personas lesbianas, gays, bisexuales, travestis y transexuales (LGBT) se ven afectadas por juicios y violencia psicológica, física y/o sexual debido a su orientación sexual. Objetivo. Analizar la asociación entre violencia, uso de drogas y suicidio en personas LGBT. Método. Entrevistamos a 316 personas LGBT de dos ciudades del Noreste brasileño por medio de un instrumento estructurado. Esto incluyó preguntas sobre datos sociodemográficos, orientación sexual, tipo de violencia, tipo y cantidad de drogas consumidas y suicidio. Resultados. Se encontró una asociación positiva entre la violencia física y el consumo de anabólicos $(p=.001)$ y tranquilizantes $(p=.012)$. En relación con la violencia psicológica y verbal, hubo una asociación positiva con el uso de tranquilizantes $(p=.021)$ y negativa con el uso de anfetaminas ( $p=$ $.027)$. Los intentos de suicidio se asociaron con la violencia física $(p=.03)$ y sexual $(p=.037)$. El consumo de drogas, especialmente éxtasis, cocaína, marihuana y tranquilizantes, se asoció también con intentos de suicidio ( $p=.002, p=.031, p<.001, p<.001$, respectivamente). Los participantes que ya habían intentado suicidarse eran más vulnerables a experimentar violencia y consumir drogas dentro de los 30 días previos a la entrevista $(p<.001)$. Discusión y conclusión. La violencia psicológica/verbal se asoció con el uso de anfetaminas, mientras que la violencia física se asoció con un mayor consumo de tranquilizantes y esteroides anabólicos. Los intentos de suicidio fueron más comunes entre los participantes que habían sufrido violencia física y que consumían sustancias como el éxtasis, la cocaína, la marihuana y los tranquilizantes.

Palabras clave: Homosexualidad, bisexualidad, violencia, medicamentos psicotrópicos. 


\section{INTRODUCTION}

Violence is a complex global public health problem because it harms the human rights and mental health of its victims (Silva, Coelho, \& Pires, 2014; Souza, Malvasi, Signorelli, \& Pereira, 2015; Hatzenbuehler, Mphil, McLaughlin, \& Hasin, 2010). Lesbian, gay, bisexual, transvestite, and transgender (LGBT) people are affected by prejudice and psychological, physical, and/or sexual violence due to their sexual orientation (non-heterosexual) (Souza et al., 2015; Pellulo, Giuseppe, \& Angelillo, 2013).

Estimates suggest that since 1990 approximately one third of the LBGT population has experienced some form of interpersonal violence (Pellulo et al., 2013; Fassinger, 1991; Barrientos-Delgado, Cárdenas-Castro, \& Gómez-Ojeda, 2014). In Brazil, for example, an increase of more than $180 \%$ in homophobic violence has been observed in the last few years, with an average of 13.29 victims per day (Ministério da Saúde, 2011; 2012).

Some authors agree that experiences of prejudice and violence encourage the early and abusive use of licit and illicit drugs among LGBT people. The continuous use of these substances predisposes them to develop mental disorders such as anxiety and depression, and even lead them to attempt suicide (McCabe, Bostwick, Hughes, West, \& Boyd, 2010; Traube, Holloway, Schrager, \& Kipke, 2012).

Meta-analysis of 25 population-based studies revealed that the lifetime prevalence of suicide attempts among gay and bisexual men is four times higher compared to heterosexual men. In lesbian and bisexual women, the values are twice that in all women (King et al., 2008). In a review study, the analysis of 16 studies showed that the prevalence of suicide attempts in LGBT people was between $20 \%$ 53\% (McDaniel, Purcell, \& D’Augelli, 2001).

In this context, there is evidence that Latino and Asian LGBT individuals are at an increased risk for suicidal behavior because of the stigma associated with non-heterosexual behavior in Latin cultures, in which collectivism and family honor predominate (Meyer, Dietrich, \& Schwartz, 2008).

The relationship between violence suffered, drug use, and suicide in LGBT individuals is not clear, as the concomitant association of these variables has not been analyzed in previous publications. In the LBGT population, studies have only observed the relationships between drug use and sexual violence, discrimination and prejudice, and between child sexual abuse and family violence (de Santis, Gonzalez-Guarda, Provencio-Vasquez, \& Deleon, 2014; Buller, Devries, Howard, \& Bacchus, 2014; Wong, Weiss, Ayala, \& Kipke, 2010; Marshal, Burton, Chisolm, Sucato, \& Friedman, 2013; Friedman et al., 2011; Kecojevic et al., 2012).

Despite the high occurrence of factors related to suicidal behaviors in Brazilian LGBT people, it is suggested that the gaps in knowledge about the phenomenon result from a combination of many components, including the low priority and scarce funding directed to studies about sexual minority groups, difficulties inherent in studying and recruiting this population, and the omission of sexual orientation as a variable in sociodemographic studies on suicide and mental health (King et al., 2008).

In view of the above, the objective of this article is to analyze the prevalence of violence and drug use and its association with suicide attempts in lesbian, gay, bisexual, transvestite and transsexual people.

\section{METHOD}

\section{Study design}

Analytic cross-sectional study developed in the municipalities of Juazeiro do Norte (240000 inhabitants and .69 of Human Development Index [HDI]) and Crato (122,000 inhabitants and HDI $=.71)$ in the Northwest of Brazil (Governo do Estado do Ceará, 2013).

\section{Sample}

To calculate the sample size, we have adopted the recommendations proposed by Lwanga and Lemeshow (1991), assuming a prevalence of violence of $50 \%$; absolute accuracy of $6 \%$; and a significance level of $5 \%$. The estimated sample size was 267 individuals. To allow for losses and refusals, a convenience sample of 400 individuals was recruited in a LGBT festival called "LGBT Pride Parade", held in July 2013, in both cities. Among the 400 people approached, 30 were excluded because they were only surprising or sympathizers and 54 declined the invitation. The final sample was composed of 316 people the self-declared gay, lesbian, bisexual or transgender (transvestite or transsexual) (Figure 1).

\section{Data collection}

All the information was collected during face-to-face structured interviews conducted by trained health professional

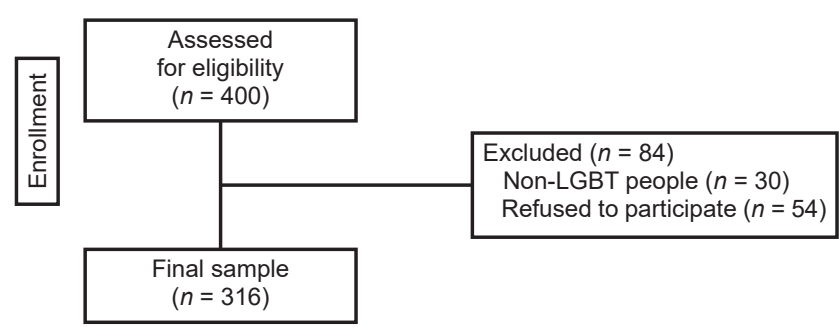

Figure 1. Flow chart of the inclusion of the participants throughout the study. 
in reserved places for approximately 20 minutes. At the end of each interview, the participants received stickers with the message "I participated in the research" so as to avoid interviewing the same person again.

At this moment, the participants filled out a structured form with the variables: sociodemographic profile, kind of violence, drug consumption, and suicide attempt. This form was tested among LGBT people (about 10) from some other place and situation; these data were not included in our study.

\section{Variables}

Sociodemographic variables were: biological sex (male and female), schooling (complete or incomplete elementary school, high school, superior education, and postgraduation), marital status (single, dating, in a stable relationship, married, divorced, and widowed), formal work (yes and no), age (years) and monthly income. For this study, "consensual marriage" refers to an enduring relationship between two people with the purpose of having a family, but without formalizing the civil marriage (Zarias, 2010).

Sexual orientation was assessed by the question: "Which category best describes you?" The options were gay, lesbian, bisexual, or transgender (transvestite or transsexual). Violent events were classified into psychological or verbal, physical, and sexual. In this moment of the interview, the participants were asked to specify the kind of aggression they had suffered, because of the subjective nature of this situation (minimization of bias).

The consumption of the following drugs within the last thirty days was investigated: alcohol, tobacco, non-opiate analgesics, marijuana, cocaine, hallucinogenic drugs, amphetamines, ecstasy, tranquilizers, anabolic steroids, and others. Suicide attempts were measured based on the "yes" or "no" answer to the question: "Have you ever attempted suicide in life?"

\section{Data analysis}

Qualitative variables were expressed as absolute and relative frequencies, and quantitative variables, as median and 25 and 75 percentiles, due to the non-normal distribution $(p<.05$ - Shapiro-Wilk test). The incidence ratio for suicide attempts according to violence and drug use was estimated by Poisson Regression (log-binominal model) with robust variance (Wilber \& Fu, 2010). The frequency of violence and drug use is presented as medians and respective confidence intervals, and the differences were checked using Mann-Whitney test.

The association between violence suffered throughout life and drug consumption (in the last 30 days) was evaluated by the Chi Square Person test. On the other hand, in order to analyze the relation between the quantity of violent events and drug consumption, we adopted the Kruskal-Wallis test. The Stepwise backward strategy for modeling was used to estimate the incidence ratio in the multivariate Poisson regression. The entry and remove criteria were $p=.05$ and $p=.2$, respectively and all sociodemographic, violence types, and drug use variable were used for adjustment. We applied a confidence interval of $95 \%$ in all data analyses, which were conducted on the version 11.0 of the Stata statistical software.

\section{Ethical considerations}

This research was approved by the Research Ethical Committee of the ABC Faculty of Medicine, Santo André, Brazil, under process number 19018513.0.0000.0082. All participants signed an informed consent before participating in this investigation. Respondents were identified by numbers in the tables and statistical analyses.

\section{RESULTS}

All participants had already suffered some type of violence. Drug consumption occurred in $84 \%$ (no answers) to $89 \%$ (answers) of the sample. There was no statistically significant difference between type of violence suffered and type of drug used $(p>.05)$. There was no statistically significant difference between groups (answers and no answers) in relation to sociodemographic variables $(p>.20)$.

\section{Sociodemographic profile and sexual orientation}

Participants were mostly brown skinned (62\%), consensually married (64.2\%), with complete high school (34.2\%) and had mostly informal employment (54.1\%). The mean ( \pm standard deviation) of monthly income and age were USD $304.82(S D \pm 283.3)$ and $24.3(S D \pm 7.0)$ years, respectively. Most participants were male $(70.6 \%)$, male gender identity $(63.3 \%)$, and homosexually orientated gay $(51.3 \%)$.

Among the LGBT population, there was a predominance of gays, lesbians, and bisexuals $(92.4 \%)$ in relation to transgender $(9.6 \%)$. The LGB population had a higher income than the transgender $(p<.001)$. However, this variable (LGB versus transgender group) had no influence on the final model or at least did not remain after adjustments with other variables. In addition, we did not identify statistically significant differences between these groups (LGB versus transgender) as regards marital status $(p=.971)$, with those who lived $(p=.840)$, children $(p=.644)$, and employment $(p=.150)$ (Table 1). 
Table 1

Sex, gender and sociodemographic characteristics of lesbians, gays, bisexuals and transgenders, 2013

\begin{tabular}{lcc}
\hline Characteristic & $N$ & $\%$ \\
\hline Biological sex & & \\
$\quad$ Male & 185 & 74.0 \\
$\quad$ Female & 65 & 26.0 \\
Sexual orientation & & \\
$\quad$ Homosexual & 208 & 83.2 \\
$\quad$ Bisexual & 42 & 16.8 \\
Marital status & & \\
$\quad$ Married & 9 & 3.6 \\
Divorced & 1 & .4 \\
Stable relationship & 18 & 7.2 \\
Dating & 62 & 24.8 \\
Single & 160 & 64.0 \\
Formal job & & \\
Yes & 102 & 42.0 \\
No & 141 & 58.0 \\
& Median (p25 $-\mathrm{p} 75)^{\mathrm{a}}$ \\
Age & 21 & $19-27$ \\
Income & 678 & $300-850$ \\
\hline
\end{tabular}

Note: ap25 - p75: percentiles 25 and 75, respectively; Of the total of homosexuals: Gays $(n=137,54.8 \%)$, Lesbians $(n=52,20.8 \%)$ and Transgenders $(n=19,7.6 \%)$

\section{Prevalence of violence and drug consumption}

The prevalence of psychological/verbal, physical, and sexual violence throughout life was $78.8 \%, 31.3 \%$, and $18.4 \%$, respectively. Participants reported using one or more licit and/or illicit drugs: alcohol (71.4\%), tobacco (22.7\%), analgesics $(17.9 \%)$, opioid analgesics $(16.9 \%)$, tranquilizers $(7.7 \%)$, cocaine $(7.3 \%)$, marijuana $(3.6 \%)$, amphetamines (3.6\%), anabolic steroids $(2.3 \%)$, ecstasy $(2.2 \%)$, and hallucinogen (1.8\%).

Table 2

Incidence and incidence ratio of suicide attempt according to type of violence experienced

\begin{tabular}{lccc}
\hline & $\begin{array}{c}\text { Incidence } \\
\text { of suicide } \\
\text { attempt }(\%)\end{array}$ & $\begin{array}{c}\text { Incidence ratio } \\
(95 \% \mathrm{Cl})^{*}\end{array}$ & $\begin{array}{c}p \\
\text { value* }^{*}\end{array}$ \\
\hline Experienced violence & 11.7 & 1 & - \\
$\quad$ No & 27.1 & $2.31(1.34-3.99)$ & .003 \\
$\quad$ Yes & & & - \\
Sexual & 14.9 & 1 & - \\
$\quad$ No & 26.8 & $1.79(1.03-3.10)$ & .037 \\
Yes & & & - \\
Psychological and verbal & \\
No & 0.0 & - & - \\
Yes & 18.7 & - & - \\
\hline
\end{tabular}

Note: blt was not possible to estimate incidence ratio since the incidence of suicide attempts in the group not experience psychological and verbal violence was $0 \%$; ${ }^{\circ}$ Estimated using Poisson multiple regression, with robust variance; $95 \% \mathrm{Cl}$ - $95 \%$ confidence interval.

\section{Association between violence suffered and drug consumption}

Among the three types of violence analyzed in this study, only psychological/verbal and physical violence presented statistically significant associations with drug consumption within the last 30 days. Based on the participants' reports, it is possible to conclude that anabolic steroids (5.9\%) and tranquilizers $(7.9 \%)$ were consumed exclusively by LGBT people who had suffered physical violence $(p=.001)$ and psychological/verbal violence $(p=.027)$, respectively. Moreover, tranquilizers (11.6\%) and amphetamines $(8.8 \%)$

Table 3

Incidence and incidence ratio (95\% confidence interval) of suicide attempt according to type of drug used in lesbians, gays, bisexuals and transgenders, 2013

\begin{tabular}{|c|c|c|c|}
\hline Drugs & $\begin{array}{l}\text { Incidence } \\
\text { of suicide } \\
\text { attempt (\%) }\end{array}$ & $\begin{array}{l}\text { Incidence ratio } \\
(95 \% \mathrm{Cl})^{*}\end{array}$ & $p$ value* \\
\hline \multicolumn{4}{|c|}{ Alcohol } \\
\hline No & 15.9 & 1 & - \\
\hline Yes & 21.5 & $1.35(.71-2.57)$ & .354 \\
\hline \multicolumn{4}{|c|}{ Amphetamine $^{c}$} \\
\hline No & 19.5 & 1 & - \\
\hline Yes & 0.0 & - & \\
\hline \multicolumn{4}{|c|}{ Ecstasy } \\
\hline No & 17.8 & 1 & - \\
\hline Yes & 60.0 & $3.36(1.55-7.28)$ & .002 \\
\hline \multicolumn{4}{|c|}{ Cocaine } \\
\hline No & 17.3 & 1 & - \\
\hline Yes & 37.5 & $2.15(1.07-4.36)$ & .031 \\
\hline \multicolumn{4}{|c|}{ Marijuana } \\
\hline No & 15.8 & 1 & - \\
\hline Yes & 43.5 & $2.74(1.55-4.85)$ & $<.001$ \\
\hline \multicolumn{4}{|c|}{ Hallucinogens } \\
\hline No & 18.3 & 1 & - \\
\hline Yes & 50.0 & $2.73(.98-7.59)$ & .054 \\
\hline \multicolumn{4}{|c|}{ Tranquilizers } \\
\hline No & 16.3 & 1 & - \\
\hline Yes & 52.9 & $3.24(1.87-5.60)$ & $<.001$ \\
\hline \multicolumn{4}{|c|}{ Analgesics } \\
\hline No & 17.3 & 1 & - \\
\hline Yes & 25.6 & $1.48(.79-2.76)$ & .218 \\
\hline \multicolumn{4}{|c|}{ Anabolic steroids } \\
\hline No & 18.8 & 1 & - \\
\hline Yes & 20.0 & $1.06(.17-6.31)$ & .945 \\
\hline \multicolumn{4}{|c|}{ Tobacco } \\
\hline No & 15.7 & 1 & - \\
\hline Yes & 27.4 & $1.74(.98-3.08)$ & .056 \\
\hline \multicolumn{4}{|l|}{ Others } \\
\hline No & 19.0 & 1 & - \\
\hline Yes & 16.2 & $.85(.38-1.89)$ & .700 \\
\hline
\end{tabular}

Note: clt was not possible to estimate incidence ratio since the incidence of suicide attempts in the group that used amphetamines was $0 \%$; *Estimated using Poisson multiple regression, with robust variance; $95 \% \mathrm{Cl}-95 \%$ confidence interval. 
Table 4

Model of the multivariate analysis of the incidence ratio (95\% Cl) of suicide attempt according to Sociodemographic, violence types and drug use by lesbians, gays, bisexuals and transgenders, 2013

\begin{tabular}{|c|c|c|}
\hline Model & Incidence ratio $(95 \% \mathrm{Cl})$ & $p^{*}$ \\
\hline Biological sex female & $.39 \quad(.21 ; .73)$ & .003 \\
\hline Tranquilizers & $1.99 \quad(.91 ; 4.35)$ & .083 \\
\hline Ecstasy & $3.85 \quad(.96 ; 15.4)$ & .057 \\
\hline Marijuana & $3.02(1.65 ; 5.54)$ & $<.001$ \\
\hline Anabolic steroids & $4.38 \quad(.91 ; 20.9)$ & .065 \\
\hline
\end{tabular}

Note: *Estimated using Poisson multiple regression with robust variance adjusted by Sociodemographic, violence types and drug used: $95 \% \mathrm{Cl}$.

were more often consumed by people who had suffered physical violence $(p=.012)$ and who had not suffered psychological/verbal violence $(p=.021)$, respectively.

There was no statistically significant association between frequency of violence suffered throughout life and quantity of drugs consumed within the last 30 days; confidence intervals overlapped and there was a .069 probability.

There was an association between suicide attempt incidence and physical and sexual violence. The incidence ratios were $2.31(95 \%$ CI $[1.34,3.99, p=.003])$ for physical violence and $1.79(95 \% \mathrm{CI}[1.03,3.10, p=.037])$ for sexual violence (Table 2).

Concerning drug use, there was an association between suicide attempts and the use of ecstasy, cocaine, marijuana and tranquilizers, with incidence ratios of $3.36(95 \%$ CI $[1.55,7.28]), 2.15$ (95\% CI [1.07, 4.36]), 2.74 (95\% CI $[1.55,4.85])$, and 3.24 (95\% CI $[1.87,5.60])$, respectively (Table 3).

It was observed that the average frequency of violence suffered throughout life $(p<.001)$ and the frequency of drug use in the last 30 days $(p<.001)$ were higher in individuals who had attempted suicide at least once.

In the multivariate analysis, it was observed that the biological sex female decreased of the risk attempted suicide IR .39 (95\% CI $[.21, .73] ; p=.003)$ and the use of the marijuana seemed to increase twice $(95 \%$ CI $[1.65,5.54])$ this risk when adjusted by sociodemographic variables, violence types, and drug used (Table 4).

\section{DISCUSSION AND CONCLUSION}

We collected evidence indicating that the rates of violence against the LGBT population are still high in this Brazilian region. This is perhaps a reflection of the prevailing prejudice, chauvinism, and lack of specific public policies against general violence in Brazil. In fact, the annual medical expenses due to physical aggressions and transport accidents have raised by 130\% (around 690000 USD) (de
Lima, Bueno, \& Mingardi, 2016). LGBT advocacy groups in Brazil say that every 25 hours a person from this community dies because due to violence cases. In addition, for each case of violence against the LGBT population in Brazil, the police identifies the perpetrator in only $17 \%$ of the cases. According to this survey, the state of Ceará (place of this study) was the fifth in cases of murders of LGBT people (Mott, Michels, \& Paulinho, 2017).

Our findings showed a predominance of psychological/ verbal violence and the use of licit drugs, especially alcohol and tobacco. Studies in this field conducted in Brazil, United States, Italy, and Australia support these same findings in the LGBT population (Pellulo et al., 2013; McCabe et al., 2010; de Santis et al., 2014; Teixeira-Filho \& Rondini, 2012; Vieira, 2006; Laranjeira, 2014; Thiede et al., 2003; Phillips et al., 2017). The greater ease of access and purchase and low supervision justifies this finding. In addition, gay and bisexual men and lesbian women drink and smoke overall more than the heterosexual population. This issue has already emerged as a public health problem (Gearhardt, Grilo, DiLeone, Brownell, \& Potenza, 2011; Bye, Gruskin, Greenwood, Albright, \& Krotki, 2005).

The association identified between violence suffered and drug use in the LGBT population studied supports the Meyer's Minority Stress Theory model. This model proposes that sexual minorities present a higher chance to develop mental disorders and consume psychoactive substances due to discriminatory and violent social background (McCabe et al., 2010). In addition, the model proposed by Singer proposes a synergism between drug use and exposure to violence (in this case, in HIV-positive Latin and African American people) (Singer, 2006).

We believe that the higher consumption of anabolic steroids by individuals who had suffered physical violence is related to an attempt to reach a better social integration. Self-care and good body image, especially in the Brazilian culture, is much appreciated in any social environment. However, in the case of steroids, it is also possible that this phenomenon indirectly represents a strategy of promoting self-defense in future cases of homophobic violence.

A previous study concluded that it is a fact that gay men associate anabolic steroid consumption with resistance, physical strength, and virility (Sánchez, Grrenberg, \& Vilain, 2009). Another association detected was between physical violence and consumption of tranquilizers. Authors comment that victims of emotional abuse start using tranquilizing drugs early (Kecojevic et al., 2012). Due to its calming and reducing effect on psychomotor processes, these drugs can help to reduce stress and anxiety, becoming coping strategies in the face of psychological violence (Andrade et al., 2012).

We observed that the participants who had not suffered any psychological violence did not consume tranquilizers and had a higher consumption of amphetamines. This asso- 
ciation can be explained by the purpose of these substances. Amphetamines are known as recreational drugs and ancillary for sexual encounters, especially in the gay public (Morgenstern et al., 2009). Thus, if the individuals have not been victims of violence, it is justifiable to seek drugs or situations with excitatory/euphoric effects instead of a sedative effect (tranquilizers). The latter would, in turn, be the drug of choice of those who have suffered psychological violence.

Latin America is still one of the global regions with the highest number of cases of violence against LGBT people. However, data from the map of laws and sexual orientation reveal that countries such as Brazil, Argentina, and Colombia have made great strides in recent years regarding the rights of LGBT people (marriage, adoption and protection against discrimination). This may have some positive impact on rates of violence and prejudice. However, suicide cases among this population are still a public health problem, according to Brazilian and Colombian researchers (Carroll \& Ramón-Mendos, 2017; Rocha-Buelvas, 2015).

Similarly to other studies, we found that suicide attempts are associated with violence and drug use. The literature suggests that these stressors are strongly associated with suicidal behavior in the homosexual and bisexual populations (Traube et al., 2012; McDaniel et al., 2001; Rayn, Hubner, Diaz, \& Sanchez, 2009; Matthews, Hughes, Johnson, Razzano, \& Cassidy, 2002; Hughes, Johnson, Wilsnack, \& Szalacha, 2007; Cochran, Mays, Alegria, Ortega, \& Takeuchi, 2007; Blosnich \& Bossarte, 2012).

It is suggested that violence causes LGBT people to develop negative feelings towards their sexual orientation, which in turn leads to internalized homophobia, social isolation, and different levels of mental distress (Hérnandez $\&$ Torres, 2005). These factors increase the chances for depression and suicidal attempts in the group. Conflicts inherent to sexual orientation are strongly associated with negative health outcomes and quality of life, including a six-fold increased risk of depression (Rayn et al., 2009).

Among the types of violence suffered, in our study, both physical and sexual victimization were associated with suicide attempt. The data is corroborated by a study that revealed that people with a history of sexual or physical abuse were two to three times more likely to have suicidal ideation episodes and suicide attempts (Matthews et al., 2002).

In the present study, the use of tranquilizers, cocaine, marijuana, and ecstasy was associated with suicide attempts. It is important to note the implications of the prevalence of use of drugs such as ecstasy and marijuana for the occurrence of the phenomenon. In this sense, it is suggested that by disturbing the normal functioning of the central nervous system (CNS) and causing hallucinations, delusions, and illusions, these substances may predispose people to suicide. Drugs that disturb the CNS, such as ecstasy, have a higher association with suicide attempts than other types of drugs (Dos Santos, 2013; Monteiro, 2013).

The main type of violence seen in the sample studied was the psychological/verbal. This violence showed associations with the use of amphetamines, while physical violence was associated with a higher consumption of tranquilizers and anabolic steroids. Suicide attempts were higher among people who had suffered physical violence and who used drugs such as ecstasy, cocaine, marijuana, and tranquilizers.

The results of this study should be interpreted taking into account some limitations. Firstly, the data were obtained from a convenience sample. Secondly, we are not able to assess the implications of the temporal relationships between drug use, violence suffered, and suicide attempts. Furthermore, the study was not able to analyze the implications of violence and drug use with suicide attempts according to sexual orientation (gay, lesbian, bisexual, and transgender) due to the small sample size.

\section{Funding}

None.

\section{Conflict of interests}

The authors declare they have no conflict of interests.

\section{Acknowledgements}

Laboratory of Epidemiology and Data Analysis from the Faculdade de Medicina do ABC, Brazil.

\section{REFERENCES}

Andrade, S. S. C. A., Yokota, R. T. C., Sá, N. N. B., Silva, M. M. A., Araújo, W. N., Mascarenhas, M. D. M., \& Malta, D. C. (2012). Relação entre violência física, consumo de álcool e outras drogas e bullying entre adolescentes escolares brasileiros. Cadernos de Saúde Pública, 28(9), 1725-1736. doi: 10.1590/S0102311X2012000900011

Barrientos-Delgado, J., Cárdenas-Castro, M., \& Gómez-Ojeda, F. (2014). Características sociodemográficas, bienestar subjetivo y homofobia en una muestra de hombres gay en tres cuidades chilenas. Cadernos de saude publica, 30(6), 1259-1269. doi: 10.1590/0102-311X00108413

Blosnich, J. \& Bossarte, R. (2012). Drivers of disparity: differences in socially-based risk factors of self-injurious and suicidal behaviors among sexual minority college students. Journal of American College Health, 60(2), 141-149. doi: 10.1080/07448481.2011.623332

Buller, A. M., Devries, K. M., Howard, L. M., \& Bacchus, L. J. (2014). Associations between intimate partner violence and health among men who have sex with men: a systematic review and meta-analysis. PLoS Med, 11(3). doi: 10.1371/ journal.pmed.1001609

Bye, L., Gruskin, E., Greenwood, G., Albright, V., \& Krotki, K. (2005). California lesbians, gays, bisexuals and trans-gender (LGBT) Tobacco Use Survey - 2004. Sacramento, CA: California Department of Health Services, 40. Retrieved from www.cdph.ca.gov/programs/tobacco/Documents/Resources/Publications/ CTCP-LGBTTobaccoStudy.pdf

Carroll, A. \& Ramon-Méndos, L. (2017). State-sponsored homophobia - A world survey of sexual orientation laws: criminalization, protection and recognition. Geneve: ILGA. Retrieved from http://ilga.org/downloads/2017/ILGA_State_ Sponsored_Homophobia_2017_WEB.pdf 
Cochran, S. D., Mays, V. M., Alegria, M., Ortega, A. N., \& Takeuchi, D. (2007). Mental health and substance use disorders among Latino and Asian American lesbian, gay, and bisexual adults. Journal of Consulting and Clinical Psychology, 75(5), 785-794. doi: 10.1037/0022-006X.75.5.785

Dos Santos, C. B. (2013). "É proibido fumar, diz o aviso que eu li": o serviço social na promoção da saúde do usuário tabagista. Revista da Graduação, 6(2).

Fassinger, R. (1991). The hidden minority issues and challenges in working with lesbian women and gay men. The Counseling Psychologist, 19(2), 157-176. doi: $10.1177 / 0011000091192003$

Friedman, M. S., Marshal, M. P., Guadamuz, T. E., Wei, C., Wong, C. F., Saewyc, E., \& Stall, R. (2011). A meta-analysis of disparities in childhood sexual abuse, parental physical abuse, and peer victimization among sexual minority and sexual nonminority individuals. American Journal of Public Health, 101(8), 14811494. doi:10.2105/AJPH.2009.190009

Gearhardt, A. N., Grilo, C. M., DiLeone, R. J., Brownell, K. D., \& Potenza, M. N. (2011). Can food be addictive? Public health and policy implications. Addiction, 106(7), 1208-1212. doi: 10.1111/j.1360-0443.2010.03301.x

Governo do Estado do Ceará. (2013). Perfil básico municipal. Crato: Instituto de Pesquisa e Estratégia Econômica do Ceará.

Hatzenbuehler, M. L., Mphil, M. S., Mclaughlin, K. A., \& Hasin, D. S. (2010). The impact of institutional discrimination on psychiatric disorders in lesbian, gay, and bisexual populations: a prospective study. American Journal of Public Health, 100(3), 452-459. doi: 10.2105/AJPH.2009.168815

Hérnandez, L. O. \& Torres, M. I. G. (2005). Efectos de la violencia y la discriminación en la salud mental de bisexuales, lesbianas y homosexuales de la Ciudad de México. Cadernos de Saúde Pública, 21(3), 913-925. doi: 10.1590/S0102$311 \mathrm{X} 2005000300026$

Hughes, T. L., Johnson, T. P., Wilsnack, S. C., \& Szalacha, L. A. (2007). Childhood risk factors for alcohol abuse and psychological distress among adult lesbians. Child Abuse \& Neglect, 31(7), 769-789. doi: 10.1016/j.chiabu.2006.12.014

Kecojevic, A., Wong, C. F., Schrager, S. M., Silva, K., Bloom, J. J., Iverson, E., \& Lankenau, S. E. (2012). Initiation into prescription drug misuse: differences between lesbian, gay, bisexual, transgender (LGBT) and heterosexual high-risk young adults in Los Angeles and New York. Addictive behaviors, 37(11), 12891293. doi: 10.1016/j.addbeh.2012.06.006

King, M., Semlyen, J., Tai, S. V., Killaspy, H., Osborn, D., Popelyuk, D., \& Nazareth, I. (2008). A systematic review of mental disorder, suicide, and deliberate self harm in lesbian, gay and bisexual people. BMC Psychiatry, 8(1), 70. doi: 10.1186/1471-244X-8-70

Laranjeira, R. (2014). Segundo Levantamento Nacional de Álcool e Drogas Relatório 2012. São Paulo: Instituto Nacional de Ciência e Tecnologia para Políticas Públicas do Álcool e Outras Drogas. Retrieved from http://inpad.org. br/wp-content/uploads/2014/03/Lenad-II-Relat\%C3\%B3rio.pdf

de Lima, R. S., Bueno, S., \& Mingardi, G. (2016). Estado, polícias e segurança pública no Brasil. Revista Direito GV, 12(1), 49-85. doi: 10.1590/ 2317-6172201603

Lwanga, S. K. \& Lemeshow, S. (1991). Sample size determination in health studies: a practical manual. Geneva: World Health Organization. Retrieved from http:// apps.who.int/iris/handle/10665/40062

Marshal, M. P., Burton, C. M., Chisolm, D. J., Sucato, G. S., \& Friedman, M. S. (2013). Cross-sectional evidence for a stress-negative affect pathway to substance use among sexual minority girls. Clinical and translational science, 6(4), 321-322. doi: $10.1111 /$ cts. 12052

Matthews, A. K., Hughes, T. L., Johnson, T., Razzano, L. A., \& Cassidy, R. (2002). Prediction of depressive distress in a community sample of women: the role of sexual orientation. American Journal of Public Health, 92(7), 1131-1139. doi: 10.2105/AJPH.92.7.1131

McCabe, S. E., Bostwick, W.B., Hughes, T. L., West, B. T., \& Boyd, C. J. (2010). The relationship between discrimination and substance use disorders among lesbian, gay, and bisexual adults in the United States. American Journal of Public Health, 100(10), 1946- 1952. doi: 10.2105/AJPH.2009.163147

McDaniel, J. S., Purcell, D., \& D'Augelli, A. R. (2001). The relationship between sexual orientation and risk for suicide: research findings and future. Suicide Life Threatening Behavior, 31(1), 84-105.

Meyer, I. H., Dietrich, J., \& Schwartz, S. (2008). Lifetime prevalence of mental disorders and suicide attempts in diverse lesbian, gay, and bisexual popula- tions. American Journal of Public Health, 98(6), 1004-1006. doi: 10.2105/ AJPH.2006.096826

Ministério da Saúde. (2011). Relatório sobre violência homofóbica no Brasil: Ano de 2011. Brasília: Secretaria de Direitos Humanos. Retrieved from http://www.sdh. gov.br/assuntos/lgbt/pdf/relatorio-violencia-homofobica-2011-1

Ministério da Saúde. (2012). Relatório sobre violência homofóbica no Brasil: ano de 2012. Brasília: Secretaria de Direitos Humanos. Retrieved from http://www.sdh. gov.br/.../pdf/relatorio-violencia-homofobica-ano-2012

Mott, L., Michels, E., \& Paulinho. (2017). Assassinatos de LGBT no Brasil: relatório de 2016. Salvador: Grupo Gay da Bahia. Retrieved from: https://homofobiamata.files.wordpress.com/2017/01/relatc3b3rio-2016-ps.pdf

Monteiro, R. M. P. (2013). Álcool e outras drogas: diálogos sobre um mal-estar contemporâneo. Cadernos de Saúde Pública, 29(8), 1693-1694. doi: 10.1590/0102311XRE020813

Morgenstern, J., Bux, D. A. J., Parsons, J., Hagman, B. T., Waingberg, M., \& Irwin, T. (2009). Randomized trial to reduce club drug use and HIV risk behaviors among men-who-have-sex-with-men (MSM). Journal of Consulting and Clinical Psychology, 77(4), 645-656. doi: 10.1037/a0015588

Pellulo, C. P., Giuseppe, G. D., \& Angelillo, I. F. (2013). Frequency of discrimination, harassment, and violence in lesbian, gay men, and bisexual in Italy. PloS One, 8(8). doi: 10.1371/journal.pone.0074446

Phillips, G., Turner, B., Salamanca, P., Birkett, M., Hatzenbuehler, M. L., Newcomb, M. E., ... Mustanski, B. (2017). Victimization as a mediator of alcohol use disparities between sexual minority subgroups and sexual majority youth using the 2015 National Youth Risk Behavior Survey. Drug and Alcohol Dependence, 178, 355-362. doi: 10.1016/j.drugalcdep.2017.05.040

Rayn, C., Huebner, D., Diaz, R. M., \& Sanchez, J. (2009). Family rejection as a predictor of negative health outcomes in white and Latino lesbian, gay, and bisexual young adults. Pediatrics, 123(1), 346-52. doi: 10.1542/peds.2007-3524

Rocha-Buelvas, A. (2015). El riesgo suicida y los significados de las minorías sexuales: un nuevo reto para la salud pública. Revista de la Facultad de Medicina, 63(3), 537-544. doi: 10.15446/revfacmed.v63n3.43219

Sánchez, F. J., Greenberg, S. T., \& Vilain, E. (2009). Reported Effects of Masculine Ideals on Gay Men. Psychology of Men \& Masculinity, 10(1), 73-87. doi: 10.1037/a0013513

de Santis, J. P., Gonzalez-Guarda, R., Provencio-Vasquez, E., \& Deleon, D. A. (2014). The Tangled Branches (Las Ramas Enredadas): Sexual risk, substance abuse, and intimate partner violence among hispanic men who have sex with men. Journal of Transcultural Nursing, 25(1), 23-32. doi: 10.1177/1043659613504110

Silva, A. C. L. G., Coelho, E. B. S., \& Pires, R. O. M. (2014). O que se sabe sobre o homem autor de violência contra a parceira íntima: uma revisão sistemática. Revista Panamericana de Salud Publica, 35(4), 278-283.

Singer, M. (2006). A dose of drugs, a touch of violence, a case of AIDS, part 2: Further conceptualizing the SAVA syndemic. Free Inquiry in Creative Sociology, 34(1), 39-54

Souza, M. H. T., Malvasi, P., Signorelli, M. C., \& Pereira, P. P. G. (2015). Violência e sofrimento social no itinerário de travestis de Santa Maria, Rio Grande do Sul, Brasil. Cadernos de Saúde Pública, 31, 767-776. doi: 10.1590/0102$311 \mathrm{X} 00077514$

Teixeira-Filho, F. S. \& Rondini, C. A. (2012). Suicide thoughts and attempts of suicide in adolescents with hetero and homoerotic sexual practices. Saúde \& Sociedade, 21(3), 651-667. doi: 10.1590/S0104-12902012000300011

Thiede, H., Valleroy, L. A., Mackellar, D. A., Celentano, D. D., Ford, W. L., Hagan, H., ... Torian, L. V. (2003). Regional patterns and correlates of substance use among young men who have sex with men in seven US urban areas. American Journal of Public Health, 93(11), 1915-1921. Retrieved from http://www.ncbi. nlm.nih.gov/pmc/articles/PMC1448076/

Traube, D. E., Holloway, I. W., Schrager, S. M., \& Kipke, M. D. (2012). Utilizing Social Action Theory as a framework to determine correlates of illicit drug use among young men who have sex with men. Psychology of Addictive Behaviors, 26(1), 78-88. doi: 10.1037/a0024191

Vieira, N. A. (2006). Entendendo quem entende: comportamentos, atitudes e práticas de risco e de prevencao para aids entre homens que fazem sexo com homens (Master's thesis). Available from http://www.cpqam.fiocruz.br/bibpdf/2008vieira-na.pdf 
Wilber, S. T. \& Fu, R. (2010). Risk ratios and odds ratios for common events in crosssectional and cohort studies. Academic Emergency Medicine, 17(6), 649-651. doi: 10.1111/j.1553-2712.2010.00773.x

Wong, C. F., Weiss, G., Ayala, G., \& Kipke, M. D. (2010). Harassment, discrimination, violence and illicit drug use among men young men who have sex with men. AIDS Education and Prevention, 22(4), 286-298. doi: 10.1521/ aeap.2010.22.4.286

Zarias, A. (2010). A família do direito e a família no direito: a legitimidade das relações sociais entre a lei e a Justiça. Revista Brasileira de Ciência e Sociedade, 25(74), 61-76. doi: 10.1590/S0102-69092010000300004 